\title{
ASSISTIVE TECHNOLOGIES IN THE CONTEXT OF INCLUSIVE
}

УДК $378.013+371.03$

DOI https://doi.org/10.32843/2663-

5208.2020.12-2.34

\section{Постоян Т.Г.}

к.пед.н., доцент кафредри освітнього менеджменту та публічного управління Національний педагогічний університет імені К.Д. Ушинського
Розвиток цисррових пристроїв та IКT змінює процес навчання та розвитку людини, проте використання ІКТ в інклюзивній освіті не досить досліджено. У статті аналізуються теоретичні засади використання розвивальних IKT та асистивних технологій в інклюзивній освіті; представлено досвід роботи Центру реабілітації дітей ім. Бориса Литвака (м. Одеса) та анкету самооцінки готовності педагогів до використання розвивальних IKT, асистивних технологій в освітньому процесі. У дослідженні викори стано методи: аналізу, синтезу законодавчих, педагогічних, психологічних, корекційних психо-педагогічних, нормативних джерел; порівняння, класифрікації та систематизації, що дало змогу класифрікувати асистивні технології; спостереження, індивідуальні бесіди дали змогу розробити анкету готовності педагогів до використання розвивальних IKT та асистивних технологій в освітньому процесі. У статті зазначається, що процес інтеграції передбачає приведення потреб особистості з психічними та фрізичними порушеннями у відповідність до системи освіти. Наголошується, що стандартизований освітній процес не дає змогу враховувати різноманітність культур, властивих різним групам осіб з особливими освітніми потребами, а IKT сприяють реалізації та підтримці такого різноманіття за умови забезпечення сумісності продукту IKT з асистивними технологіями, що дають особам $з$ обмеженими можливостями посередницький інтерсрейс зі способами взаємодії, форматами виведення даних, відповідними їхнм фоізичним можливостям. Розглянуто досвід використання асистивних технологій у Центрі реабілітації дітей. Представлено розроблену анкету самооцінки готовності педагогів до використання IKT та асистивних технологій. Зазначено, що інклюзивна освіта потребує компетентності педагогів у сфрері розвивальних IKT та асистивних технологій.

Ключові слова: IKT, асистивні технології, особи з особливими освітніми потребами, інклюзивна освіта, досвід центру реабілітації, готовність педагогів до використання розвивальних IKT та асистивних технологій, анкета.

The development of digital devices and information and communication technologies changes the process of human learning and development, nevertheless, but the using of the ICT in the inclusive education isn't studied enough. The article analyzes the theoretical foundations of the using of the developing ICT and assistive technologies in the inclusive education; it is presented the experience of the Children's Rehabilitation Center and questionnaire self-assessment of teachers' readiness to use the developing ICT, the assistive technologies in the educational process. The study used such methods: analysis, synthesis of legislative, pedagogical, psychological, correctional psycho-pedagogical and normative sources; methods of comparison, classification and systematization, which allowed to classify the assistive technologies; observation, individual interviews, which allowed to develop a profile of the teachers' readiness to use the developing ICT and assistive technologies in the educational process. The article notes that a standardized educational process does not allow taking into account the diversity of cultures inherent in different groups of persons with special educational needs, while the ICT contribute to the realization and support of such diversity, granted the ICT products are compatible with the assistive technologies that provide individuals with special educational needs with an intermediary interface with interaction methods, data output formats corresponding to their physical capabilities. The experience of using assistive technologies at the Children's Rehabilitation Center is considered. The developed self-assessment questionnaire of the teachers' readiness to use the ICT and assistive technologies is presented.

Key words: ICT, assistive technologies, persons with special educational needs, inclusive education, teachers' readiness to use the ICT and assistive technologies, questionnaire.
Реформування вітчизняної інклюзивної освіти загалом і системи управління ї̈ якістю зокрема потребують модернізації процесу освітнього менеджменту. Успішне виконання завдань інклюзивної освіти безпосередньо залежить від ефективності дидактичних методів та інноваційних розвивальних технологій. У такому контексті вкрай важливим $є$ питання професійних кадрів (педагогічних, технічних), здатних до широкого використання IKT та асистивних технологій, їх налаштування, навчання користувачів з подальшим коригуванням. Без реалізації цих ключових позицій використання асистивних технологій здебільшого виявляється неефективним.

Мета та завдання дослідження полягали в аналізі теоретичних засад проблеми вико- ристання розвивальних IКT та асистивних технологій в інклюзивній освіті; аналізі досвіду використання таких технологій в освітній діяльності Центру реабілітації дітей-інвалідів імені Бориса Литвака (м. Одеса); розробці діагностичного інструментарію самооцінки готовності педагогів до використання розвивальних IKT та асистивних технологій в освітньому процесі.

Конвенцію ООН «Про права інвалідів» ратифіковано 177 державами світу, серед яких - і Україна. Відповідно до принципу Конвенції «Нікого не залишити без уваги» особи, які страждають хронічними захворюваннями, повинні бути включені в життя суспільства і мати можливість вести здорове і гідне життя. 
Стаття 9 Конвенції доступність IКT визначає як невід'ємну частину прав на «доступність» нарівні 3 доступністю фізичного оточення і транспорту.

Конвенція спрямовує використання потенціалу IKT у сфері нових асистивних рішень на користь осіб з обмеженими можливостями [3].

У доповіді ЮНЕСКО «Освіта в інформаційному суспільстві і для цього суспільства» наголошується, що IКT - це рушій зростання, інструмент, що допомагає розширити права і можливості людей. IKT здатні зробити вирішальний вплив на зміну освіти та її покращення [2].

Проблема використання IKT у системі корекційної психо-педагогіки знайшла відображення в Положенні про інформаційно-комунікаційні технології, що $є$ соціально значущим нормативним документом щодо забезпечення прав людей з обмеженими можливостями. Зміст Положення визначає цифрову доступність та асистивних технологій, націлює на те, щоб значний потенціал IKT у галузі нових асистивних рішень використовувався на користь осіб з обмеженими можливостями [11].

Асистивні технології класифікуються за функціональним призначенням залежно від категорії порушень у потенційних користувачів, а саме:

1) із сенсорними порушеннями, зокрема:

- з вадами зору (тіфлоінформаційні технології) [9];

- 3 порушеннями слуху (сурдоінформаційні технології) [5];

- 3 вадами мовлення (голосоутворювальні технології) [7];

2) із фізичними вадами в роботі опорнорухового апарату (моторними порушеннями) [6];

3) із когнітивними порушеннями [5];

4) з обмеженнями за загальмедичними показниками [10].

К. Ебботт та інші дослідники зазначають, що надання освітніх послуг на базі асистивних технологій ґрунтується на медичних показниках [10].

Рамочна програма дій «Освіта - 2030» (Інчхонська декларація) закликає держави забезпечити інклюзивну, якісну освіту на рівноправних засадах, а також надати можливість кожному члену суспільства здобувати освіту впродовж усього життя [8].

У контексті інформатизації інклюзивної освіти бачиться визначальною ідея Л. Виготського щодо включення нового засобу в діяльність людини, що перебудовує структуру цієї діяльності (поведінки), дає змогу виключити низку процесів, роботу яких виконує новий інструмент, що викликає до життя низку нових функцій, пов'язаних з використанням цього інструменту та управління ним [1].
В освітній обіг увійшов термін е-інклюзії (e-inclusion), що визначає застосування цифрових технологій для розвитку інклюзивної освіти. В е-інклюзії цифрові технології - це сукупність цифрових пристроїв та ITК. Дослідження проблем е-інклюзії у теорії і практиці зумовлена бурхливим розвитком цифрових пристроїв і IKT, що стрімко змінює спосіб життя сучасної людини, в тому числі і процес навчання; змінює методи, що застосовуються в загальній та спеціальній освіті. Зазначимо, що е-інклюзію важливо розглядати як шлях розширення соціальної інклюзії загалом [10].

К. Ебботт акцентує увагу на необхідності переорієнтації досліджень використання цифрових технологій в інклюзії та проблеми, які при цьому виникають на дидактичний аспект. Такі дослідження, наголошує вчений, дадуть змогу оцінити внесок саме цифрових технологій, а не роль педагога або інших чинників [10, с. 7]. У такому контексті К. Ебботт виділяє три напрями досліджень:

- використання цифрових технологій для тренування і повторення;

- використання цифрових технологій для допомоги (assist) у навчанні;

- використання цифрових технологій для розширення можливостей (enable) навчання.

Окреслюючи перспективи розвитку цифрових технологій, дослідник зазначає, що цифрові технології для тренування і повторення будуть затребуваними і надалі, але залишається не досить дослідженим їх потенціал на засадах інноваційних підходів сучасної освіти. Технології, що допомагають у навчанні, на його думку, чекають революційні зміни, що пов'язано з розробками неінвазивних методів контролю програмного забезпечення мозком, наприклад: відстеження направлення погляду, голографічних 3D-репрезентацій. Для розвитку технологій, що створюють можливості для навчання, важливим, на думку К. Ебботта, $\epsilon$ розуміння педагогами потенціалу та обмежень цифрових технологій для просування е-інклюзії, що теж вимагає відповідних досліджень [10, с. 24-25].

Отже, використанння IKT не викликає сумнівів, однак постає проблема, яку необходимо вирішувати: яким чином продукти IKT можна зробити доступними для осіб з обмеженими можливостями?

Продукт IKT вважається доступним для певної категорії осіб, якщо вони можуть використовувати його в базовому виконанні з незначним доведенням або зі зміною конфігурації, або у сукупності з певною асистивною технологією.

Багато людей з обмеженими можливостями взаємодіють 3 IK-технологіями за допомогою персональнихасистивних технологій. Асистивна технологія - це технологія забезпечення можли- 
востей, тобто технологія забезпечення доступу до інформації, спілкування або середовища. Асистивні технології покликані задовільнити широкий спектр потреб - від фізичних недоліків, таких як нездатність ефективно працювати з мишею або клавіатурою, до сенсорних проблем, коли у разі втрати зору чи слуху екран або звукові пристрої стають менш корисними; порушення читання і письма за дислексії.

Асистивні технології включають низку технологічних рішень - від простих пристроїв на кшталт слухових апаратів до складних програм перетворення тексту на мовлення (скрінрідер), використання програмних додатків, доступу на вебсторінки тощо. Асистивні технології дають особам з обмеженими можливостями стандартний посередницький інтерфейс з такими способами взаємодії і форматами виведення даних, які відповідають їхнім фізичним можливостям.

З огляду на вищезазначене, високу інтерактивність і відносну доступність комп'ютерної техніки, не можна недооцінювати потенційну ефективність корекційних дидактичних методів із застосуванням сучасних IKT, сполучених з асистивними технологіями у разі створення спеціалізованих програм для дітей з проблемами розвитку з урахуванням закономірностей і специфічних особливостей кожної дитини.

Основною метою застосування розвивальних IKT у процесі реабілітації дітей з проблемами розвитку $є$ стимулювання інтелектуальної діяльності дитини, формування й удосконалення вищих психічних функцій: уваги, пам'яті, просторових і конструкторських орієнтацій, мови, логічного мислення; стимулювання рухової недостатності, розвитку сенсомоторної координації, формування усвідомлених і цілеспрямованих рухових функцій.

У контексті зазначеного видається доцільним використання досвіду Центру реабілітації дітей-інвалідів імені Бориса Литвака (м. Одеса). У структурі Центру ефективно працює навчальний комп'ютерний центр під керівництвом Д. Індє. Навчальний комп'ютерний центр впроваджує IKT у практику роботи з корекції пізнавальної сфери дітей з проблемами розвитку. Використання IKT забезпечує різноманітність педагогічних стратегій для навчання дітей з обмеженими можливостями різної нозології, сприяє задоволенню їхніх індивідуальних потреб, особистісному розвитку, включенню дитини в розвивальне і суспільне середовище.

у навчальному комп'ютерному центрі понад десять років практикуються розвивальні заняття з використанням асистивних технологій для дітей з нейром'язовими порушеннями, важкими соматичними захворюваннями і порушеннями психічних функцій. Корекційний складник роботи з використанням асистивних технологій передбачає розвиток і корек- цію: уваги, пам'яті, мовлення, мислення, рухів та розвиток особистості.

Досвід роботи Центру підтверджує, що правильно організована рання корекція попереджує появу вторинних відхилень у розвитку дитини, забезпечує максимальну реалізацію потенціалу її розвитку, а для значної частини дітей забезпечує їхнє включення у освітнє середовище на ранньому етапі вікового розвитку.

Робота на комп'ютері 3 використанням асистивних технологій передбачає такі етапи:

- діагностику (бесіду, анкетування, спостереження, вивчення документації користувача).

- підбір програми (чи написання індивідуальної програми з урахуванням нозології користувача);

- планування роботи (перспективне, календарно-тематичне);

- проведення системи занять за обраною програмою;

- підбиття підсумків, визначення результатів роботи (діагностика, тестування).

Індивідуальна робота передбачає знайомство з асистивним пристроєм, новими програмами, формування навичок роботи з екраном і клавіатурою, офісним пакетом, графічними програмами, Інтернетом тощо.

Значна увага у навчальному комп'ютерному центрі приділяється дітям раннього дошкільного віку. Так, з дітьми цього віку під час виконання розвивальних комп'ютерних вправ використовується спеціалізована клавіатура з великими клавішами у формі геометричних фігур різного кольору, яка пристосована під моторику кисті руки дітей раннього дошкільного віку. Це покращує координацію рухів дитини, розвиває дрібну моторику, дає можливість дитині самостійно керувати програмою. Спеціальна клавіатура забезпечує виконання завдань, з якими дитина може впоратися самостійно, наприклад опанування знань щодо основних кольорів та геометричних форм тощо.

Виконання комп'ютерних завдань за допомогою спеціалізованої клавіатури дає змогу знайомити дітей з навколишнім світом, допомагає розвивати їхні творчі здібності, забезпечує опановування дітьми соціальних навичок та навичок спілкування. Разом із тим завдання, що пропонуються, спрямовані на розвиток здатності дитини слухати, на формування у неї позитивних емоцій, розвиток упевненості, самостійності та самоконтролю дитини.

Багаторічний досвід роботи навчального комп'ютерного центру з дітьми з церебральним паралічем показав, що чим раніше розпочато медико-психолого-педагогічну реабілітацію, тим вона ефективніша. Для цієї категорії дітей у навчальному комп'ютерному центрі проводяться інноваційні розвивальні заняття 
у віртуальному середовищі. Під час таких занять дитина самостійно керує віртуальним ігровим, розвивальним середовищем за допомогою рухів власного тіла та за допомогою керування власним центром ваги. Виконання певних вправ розвиває велику моторику, навички балансування, стабілізує і поліпшує поставу дитини. Крім розвитку фізичних навичок, у дитини розвиваються інтелектуально-розумові функції: розрізняння форми та кольору, математичне і логічне мислення, увага, уява, фантазія.

У ході віртуальних ігор особлива увага приділяється психоемоційному розвитку дитини. Крім позитивних емоцій, система віртуальної реальності, яка дає змогу дитині доглядати й гратися з віртуальним вихованцем, сприяє закріпленню в ігровій формі навичок самообслуговування.

Керування власними діями під час віртуальних ігор відбувається за допомогою контролера рухів. Цей асистивний пристрій дитина тримає в руці, що прикріплюється ремінцем до зап'ястку.

Зазначимо, що ІКТ використовуються у комплексі з корекційними і розвивальними методами, які впливають на весь спектр відхилень розвитку дітей з ДЦП: когнітивну, рухову, психоемоційну, інтелектуальну, комунікативну та соціальну сфери.

Реалізація інклюзивних принципів у навчальному комп'ютерному центрі стала можливою завдяки постійному підвищенню рівня IКТ-компетентності педагогів, які опановують нові IКТ і форми кіберкомунікації.

Корисним є досвід роботи О. Жука, який навчає інформатики дітей з порушеннями слуху (м. Запоріжжя). У 2019 році педагог увійшов до ТОП-10 новаторів, які змінюють Україну та світ, а у 2020 році - до числа 50 найкращих учителів світу [12].

На уроках інформатики О. Жука учні користуються планшетами, 3D-ручками, 3D-окулярами, 3D-принтером, інтерактивною панеллю, квадрокоптером та роботом LEGO. На думку педагога, важливо використати всі можливості щоб залучити учнів до роботи, а не лише показати, що такими пристроями користуються у світі [4].

Узагальнюючи результати теоретичних та емпіричних досліджень, дійшли висновку, що сформованість ІКТ-компетентностей у педагогів та навичок работи у кіберпросторі $€$ значним ресурсом реалізації інклюзивних принципів. Вочевидь, що проблема діагностування готовності педагога до використання в освітньому процесі IKT та асистивних технологій є актуальною у контексті підвищення рівня якості освітнього процесу. Виходячи з цього, в ході дослідження розроблено анкету «Самооцінка готовності педагога до використання IKT та асистивних технологій в освітньому процесі», що структуровано трьома блоками про- фесійних знань та вмінь педагога інклюзивної освіти, зокрема: знання щодо мети та завдань IKT та асистивних технологій; уміння розробляти навчально-методичне забезпечення з використанням IКТ та асистивних технологій; уміння вирішувати практичні завдання з використанням IKT та асистивних технологій.

У таблиці «Самооцінка готовності педагога до використання IКT та асистивних технологій в освітньому процесі» представлено перелік професійних знань і умінь, необхідних для роботи за певною IКТ та асистивною технологією (табл. 1).

Педагог визначає власний рівень володіння відповідними знаннями та вміннями, користуючись шкалою оцінювання. Шкала передбачає оцінку від 0 до 4 балів, зокрема: 0 - не маю уявлення про ці знання й уміння; 1 - маю певні уявлення про ці знання і уміння; 2 - маю певні знання і вміння, проте їх не досить, щоб успішно використовувати в освітньому процесі цю технологію; 3 - маю знання і вміння, що скоріш досить ніж не досить для успішного використання в освітньому процесі цієї технології; 4 - маю знання і вміння, що досить для успішного використання в освітньому процесі цієї технології.

Висновки 3 проведеного дослідження. Організація і забезпечення освітнього процесу в умовах інклюзії на засадах IКT та асистивних технологій передбачає наявність фахівців з відповідними компетентностями. Нині інклюзивна освіта потребує фахівців-професіоналів у галузі IKT та асистивних технологій. Саме тому одним із пріоритетних напрямів реалізації інклюзивної освіти в Україні є підвищення кваліфікації та перепідготовка педагогів закладів освіти, освітніх устнов, включених в інклюзивну практику. Забезпечення розвитку вітчизняної інклюзивної освіти на засадах IKT вимагає реалізації спеціальних заходів комплексного характеру, зокрема:

- скорочення інформаційної нерівності в організації освітнього процесу в умовах інклюзії, в зв'язку з чим необхідно переглянути вимоги щодо забезпечення освітнього процесу закладів освіти, що працюють з особами з обмеженими можливостями різної нозології;

- включення до штатного розпису закладів освіти всіх типів посади фахівців, які забезпечують навчання осіб з обмеженими можливостями з урахуванням їхньої нозології;

- дієве підвищення кваліфікації фахівців-практиків інклюзивної освіти з проблеми використанння IКТ та асистивних технологій в освітньому процесі.

Перспектива подальших досліджень передбачає діагностування готовності педагогів, що проходять підвищення кваліфікації в системі неперервної освіти до використання ІКТ та асистивних технологій в освітньому процесі, а також розробку міждисциплінарного курсу «Асистивні тех- 


\section{Самооцінка готовності педагога до використанням IKT та асистивних технологій} в освітньому процесі

\begin{tabular}{|c|c|}
\hline Перелік професійних знань та вмінь педагога & Бал \\
\hline Знання мети та завдань IКT та асистивних технологій & \\
\hline проблеми, що вирішуються завдяки IКТ та асистивній технології & \\
\hline результатів, що можуть бути отримані після застосування IKT та асистивної технології & \\
\hline сутність IКТ та асистивної технології & \\
\hline методів та прийомів навчання, що використовуються для реалізації IКТ та асистивної технології & \\
\hline етапів роботи на комп'ютері з використанням асистивних технологій & \\
\hline методів індивідуального навчання учнів & \\
\hline $\begin{array}{c}\text { Уміння розробляти навчально-методичне забезпечення } \\
\text { з використанням ІКТ та асистивних технологій }\end{array}$ & \\
\hline плани уроків різних типів з використанням IКТ та асистивної технології & \\
\hline етапи роботи на комп'ютері з використанням асистивних технологій & \\
\hline роздаткові матеріали для самостійної работи & \\
\hline завдання самостійні учням до навчальних тем & \\
\hline завдання для групової работи учнів & \\
\hline систему диференційованих вправ для самостійного засвоєння учнями нового матеріалу & \\
\hline завдання для поточного і підсумкового контролю & \\
\hline критерії оцінки навчальної діяльності & \\
\hline Уміння вирішувати практичні завдання з використанням IKT та асистивної технології & \\
\hline $\begin{array}{l}\text { Застосовувати окремі прийоми та методи роботи, що використовуються в IКТ та асистивній } \\
\text { технології }\end{array}$ & \\
\hline проводити уроки різних типів & \\
\hline аналізувати проведені уроки та визначати причини ї недоліків & \\
\hline $\begin{array}{l}\text { навчати учнів нових прийомів освітньої діяльності, якими вони повинні користуватися, пра- } \\
\text { цюючи за допомогою ІКТ та асистивної технології }\end{array}$ & \\
\hline $\begin{array}{l}\text { оцінювати результативність використання IKT та асистивної технології, використовуючи } \\
\text { методи педагогічної діагностики }\end{array}$ & \\
\hline
\end{tabular}

нології в освітньому процесі сучасної школи» для професійної підготовки майбутніх фахівців системи інклюзивної освіти та підвищення кваліфікації педагогів закладів освіти.

\section{ЛITEPATУРA:}

1. Выготский Л.С. Педагогическая психология / ред. В.В. Давыдова. Москва: Педагогика, 1991. 480 с.

2. Институт ЮНЕСКО по информационным технологиям в образовании. ИКТ для инклюзивного образования. Аналитическая записка. Москва, 2010. URL: http://iite.unesco.org/pics/publications/ru/files/3214675. pdf (дата звернення: 23.09.2019).

3. Конвенція $\mathrm{OOH}$ про права інвалідів : ратиф. Законом України № 1767-VI від 16.12.2009. URL: https://zakon.rada.gov.ua/laws/show/995_g71 (дата звернення: 12.10.2019).

4. Марковська М. Вчитель для рівних. https://nus. org.ua/articles/vchytel-dlya-rivnyh-yak-oleksandr-zhuknalagodzhuye-kontakt-z-uchnyamy-ta-chomu-lyubytvlasni-prizvyska/ (дата звернення: 20.03.2020).

5. Набокова Л.А. Зарубежные ассистивные технологии, облегчающие социальную адаптацию лиц с нарушениями развития. Десектология. Москва, 2009. № 2. C. 84-92.

6. Набокова Л.А. Современные ассистивные устройства для лиц с нарушениями двигатель- ного аппарата. Дефектология. Москва, 2009. № 4. C. $73-80$.

7. Набокова Л.А. Современные ассистивные устройства для лиц с когнитивными нарушениями. Дефректология. Москва, 2009. № 3. С. 84-91.

8. Образование-2030. Инчхонская декларация и рамочная программа действий по осуществлению цели в области устойчивого развития. URL: https://docplayer.ru/45701108-Inchhonskayadeklaraciya.html (дата звернення: 20.03.2020).

9. Соколов В.В. Краткий обзор современных компьютерных тифрлоинформационных средств, которые могут быть использованы в процессе обучения детей с глубоким нарушением зрения. Вестник тифрлологии. Москва, 2010. № 2. С. 84-87.

10. Abbott C. E-inclusion: Learning Difficulties and Digital Technologies. Bristol : Futurelab, 2007. 32 p. URL: https://www.nfer.ac.uk/media/1829/futl66.pdf (дата звернення: 12.10.2019).

11. Guttman C. Education in and for the information society. 2003. Paris : UNESCO. URL: https://unesdoc. unesco.org/ark:/48223/pf0000135528 (дата звернення: 02.10.2019).

12. Global Teacher Prize 2020. URL: https://nus. org.ua/news/dvoye-ukrayintsiv-uvijshly-do-chysla50-najkrashhyh-vchyteliv-svitu/ (дата звернення: 20.03.2020). 